\title{
Shock Waves as a Treatment Modality for Spasticity Reduction and Recovery Improvement in Post-Stroke Adults - Current Evidence and Qualitative Systematic Review [Corrigendum]
}

Dymarek R, Ptaszkowski K, Ptaszkowska L, et al. Clin The authors apologize for this error. Interv Aging. 2020;15: 9-28

Page 9, the affiliation for Dr. Mateusz Kowal should be “2Department of Physiotherapy, Wroclaw Medical University, Wroclaw, Poland".

\section{Publish your work in this journal}

Clinical Interventions in Aging is an international, peer-reviewed journal focusing on evidence-based reports on the value or lack thereof of treatments intended to prevent or delay the onset of maladaptive correlates of aging in human beings. This journal is indexed on PubMed Central, MedLine, CAS, Scopus and the Elsevier
Bibliographic databases. The manuscript management system is completely online and includes a very quick and fair peer-review system, which is all easy to use. Visit http://www.dovepress.com/ testimonials.php to read real quotes from published authors. 